A. A developmental study of girls with trisomy X. Am J Hum Genet 1975;27:71-80.

3 Borgaonkar DS. Chromosomal variation in man. A catalog of chromosomal variants and anomalies. 2nd ed. New York: Liss, 1977.

4 Simpson JL. Disorder of sexual differentiation. Etiology and clinical delineation. New York: Academic Press, 1976.

5 King CR, Magenis E, Bennett S. Pregnancy and the Turner syndrome. Obstet Gynecol 1978;52:617-24.

6 Dewhurst J. Fertility in 47,XXX and 45,X patients. $J$ Med Genet 1978;15:132-5.

7 Mattei MG, Mattei JF, Vidal I, Giraud F. Structural anomalies of the $\mathrm{X}$ chromosome and inactivation center. Hum Genet $1981 ; 56: 401-8$.

Requests for reprints to Dr Charles R King, Department of Obstetrics and Gynecology, University of Kansas Medical Center, 39th and Rainbow, Kansas City, Kansas 66103, USA.

\section{A homozygote for pericentric inversion of chromosome 4}

SUMMARY A child with developmental and language delay was found to be homozygous for a pericentric inversion of chromosome 4 (inv(4) $(p 15 \cdot 2 q 12))$. Her normal mother and aunt are inversion heterozygotes. It is suggested that the phenotypic abnormalities may have resulted from damage at chromosomal breakpoints or from a position effect which is expressed only in homozygous form.

The incidence of pericentric inversions in the general population is quite low $(0.01 \%$ in surveys of unselected newborns), ${ }^{1}$ although higher frequencies of $1.0 \%$ to $2.8 \%$ have been reported in selected populations. $^{2-4}$

Inversions are often ascertained as a result of their occurrence in abnormal subjects but may be coincidental findings. Although inversion heterozygosity has been associated with infertility ${ }^{5}$ or reduced fertility, and high neonatal mortality, ${ }^{6}$ as well as increased risk of offspring with chromosome aberrations or mental retardation, ${ }^{7-9}$ it is the general impression that pericentric inversions are usually harmless in a single dose. The effect of homozygosity of pericentric inversions on the phenotype has not been firmly established since only a few cases have been reported. ${ }^{210-13}$

We present a developmentally and mentally retarded child who is homozygous for a pericentric inversion of chromosome 4. Her mother and maternal aunt, who are phenotypically normal, are heterozygotes. We suggest that the abnormalities Received for publication 27 March 1982. seen in this child are the result of damage at the chromosomal breakpoints or of a position effect which is expressed only in homozygous form.

\section{Case report}

A black female was first seen at 4 years 8 months of age because of developmental and severe language delay. She was the only child of a 20-year-old mother and a 21-year-old father. Consanguinity in this relationship was denied. The pregnancy was complicated by prolonged nausea and vomiting and the delivery was by caesarean section. Her birth weight was $1930 \mathrm{~g}$.

Physical examination on admission to this hospital showed a small child with a prominent forehead, mild dolichocephaly, pointed chin, and a broad nasal bridge. The eyes were deep set and the ears were large with accentuated lobes. Both height and weight $(97.8 \mathrm{~cm}$ and $14.3 \mathrm{~kg})$ corresponded to the 3 rd centile although the head circumference $(48.6 \mathrm{~cm})$ was in the normal range. The extremities were slender with long hands and feet. Muscle mass was poorly developed. Her movements were jerky and her gait was flat footed.

The patient's early development was delayed. She stood at 12 months and walked at 3 years of age. She was shown to be functioning with gross motor skills at the $2 \frac{1}{2}$ year level and with fine motor skills at the 18 to 24 month level. She achieved a cognitive developmental index of 71 and a motor developmental index of 74 on the Bailey Mental Scale and Bailey Motor Scale, respectively. Her receptive and expressive language skills were both at the 1 year level on the Receptive-Expressive Emergent Language Scale. She had a moderate bilateral sensorineural hearing loss, more severe on the right side.

The results of routine laboratory studies, including full blood count, urine analysis, blood and urine amino-acids, T4 and TSH, $x$-rays and hand pattern profile analysis were normal. An electroencephalogram was normal and a CT brain scan showed no abnormalities. Dermatoglyphic analysis showed normal palmar creases, an atd angle of $98^{\circ}$, a total finger ridge count of 115 , and seven ulnar loops, two arches, and one whorl on the fingertips.

Chromosome analysis of peripheral blood lymphocytes and skin fibroblasts showed a homozygous pericentric inversion of chromosome 4, using GTG and RBA banding. Her karyotype was 46,XX,inv(4)(pter $\rightarrow$ p15 $2:: q 12 \rightarrow p 15 \cdot 2:: q 12 \rightarrow q$ ter), inv(4)(pter $\rightarrow$ p15 $2:: q 12 \rightarrow$ p15.2::q12 $\rightarrow$ qter). The inversion appeared to be the same in both chromosomes and was present in all cells examined (figs 1a, 2). 


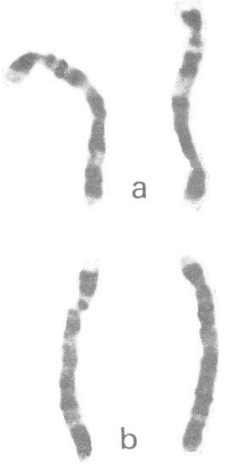

FIG 1 GTG banded chromosome 4 from (a) the patient, a homozygote, and (b) her maternal aunt, a heterozygote.
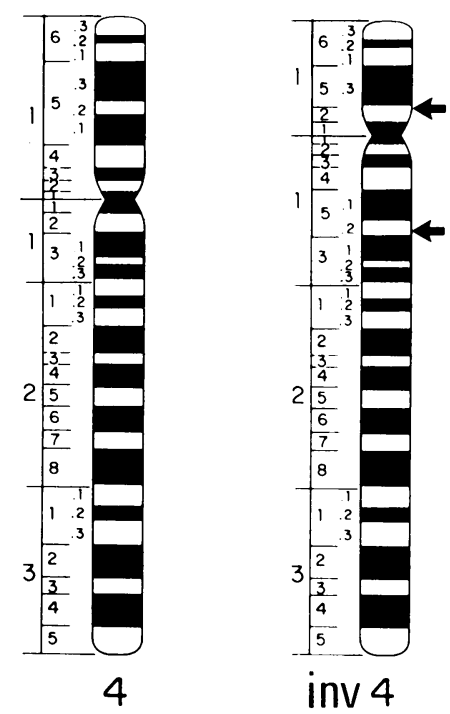

FIG 2 Diagram of the pericentric inversion indicating the inverted chromosome and breakpoints (arrows) on the right.

Chromosome studies of lymphocytes from her mother and two maternal aunts showed her mother and one aunt to be inversion heterozygotes. Their karyotypes were $46, \mathrm{XX}$,inv(4)(pter $\rightarrow$ p15.2: :q12 $\rightarrow$ p15.2::q12 $\rightarrow$ qter) (fig 1 b). The karyotype of the other aunt was normal, 46,XX. The father was not available for study.

\section{Discussion}

Homozygotes for chromosome inversions have rarely been reported. In three such families in which pericentric inversions of chromosome 9 were studied, any clinical significance of the homozygosity can be excluded. One homozygous female and her heterozygous parents were phenotypically normal while her heterozygous sister had primary amenorrhoea.$^{10}$ In the second family, a homozygote who had hyperglycinaemia was developmentally and mentally retarded. ${ }^{2}$ In the third family, the proband, a homozygote with genital anomalies, had a brother with the same phenotype although he was a heterozygote. ${ }^{12}$ The father, a homozygote, and the sister, a heterozygote, were both phenotypically normal. A somewhat similar conclusion can be drawn from one case involving a homozygous inversion of chromosome 3 in which the homozygote who was mentally retarded had a retarded sister who was a heterozvgote. ${ }^{11}$

In the present report, the pericentric inversion of chromosome 4 resulted in no apparent effect in the heterozygotes. Both the mother and maternal aunt were phenotypically normal and there was no history of infertility or miscarriages in this family. The finding of developmental delay and mental retardation in the offspring may of course be coincidental. On the other hand, it is possible that daniage from a small deletion or gene alteration may have taken place at the breakpoints on the chromosome and is expressed only in the homozygote. As position effect on the genes rearranged because of the inversion and expressed only in homozygous formo may also be considered. Finally, it is possible that the inversion in the child and her mother (and presumably her father) may not be identical. A small deletion or duplication resulting from unequal crossing over involving points of non-homologous pairing during meiosis in one of the parents may have occurred. Although consanguinity was denied, the possibility that two unrelated parents are carriers of the same rare pericentric inversion is very remote. If we conclude that the parents are related, then, of course, the possibility that the abnormal phenotype of this child may have resulted from mutant recessive alleles other than those at the chromosomal breakpoints cannot be ruled out with certainty.

Comparisons with other cases involving pericentric inversions of chromosome 4 are difficult to make because none has been reported with the same cytogenetic rearrangement. In previously reported cases of pericentric inversions of chromosome 4, the breakpoints reported have been different from those in our case. ${ }^{14-18}$ All cases have been heterozygotes who were phenotypically normal, discovered because their offspring were malformed as a result of 'aneusomie de recombinaison', or who were phenotypically abnormal with additional chromosome abnormalities such as deletions or translocations. Many patients who have visible deletions of either 
the proximal or the distal portion of the short arm of chromosome 4 have been described but they have distinctly different and much more severe malformations than our patient. ${ }^{19} 20$ In all of the cases reported with intersitital or terminal deletions of the long arm of chromosome 4, the breakpoints have been distal to that observed in our patient and the phenotypic expressions have been, for the most part, much more severe. ${ }^{21} 22$

We suggest that a pericentric inversion, which in heterozygous form has no adverse phenotypic expression, may have such an effect in homozygous form. The developmental and language delays seen in our patient may have resulted from damage of critical genetic material at the breakpoints or from a position effect caused by gene rearrangement resulting from the inversion which is expressed only in the homozygous form. However, the possibility that other recessive alleles may be involved cannot be ruled out.

We thank Mrs Tamara Sanchez for performing the chromosome analysis and Mr Hoyt Smith for the diagram.

\section{N J CARPenter, B SAy, AND N D Barber Department of Clinical Genetics, Children's Medical Center, Tulsa, Oklahoma, USA.}

\section{References}

1 Jacobs PA. Structural rearrangements of the chromosomes in man. In: Hook EB, Porter IH, eds. Population cytogenetics. New York: Academic Press, 1977:81-97.

2 de la Chapelle A, Schroder J, Stenstrand $\mathrm{K}$, et al. Pericentric inversions of human chromosomes 9 and 10. Am J Hum Genet 1974;26:746-66.

3 Madan K, Bobrow M. Structural variation in chromosome 9. Ann Genet (Paris) 1974;17:81-6.

4 McKenzie WH, Lubs HA. Q and C chromosomal variations: distribution and incidence. Cytogenet Cell Genet 1975;14:97-115.

5 Boué J, Taillemite JC, Hazael-Massieux P, et al. Association of pericentric inversion of chromosome 9 and reproductive failure in ten unrelated families. Humangenetik 1975;30:217-24.

6 Faed MJW, Marrian VJ, Robertson J, et al. Inherited pericentric inversion of chromosome 5: a family with history of neonatal death and a case of the 'cri du chat' syndrome. Cytogenetics $1972 ; 11: 400-11$.

7 Wilson MG, Towner JW, Coffin GS, et al. Inherited pericentric inversion of chromosome No 4. Am J Hum Genet 1970;22:679-90.

8 Allderdice PW, Browne M, Murphy DP. Chromosome 3 duplication q21 $\rightarrow$ qter deletion p25 $\rightarrow$ pter syndrome in children of carriers of a pericentric inversion inv(3) (p25q21). Am J Hum Genet 1975; 27:699-718.

- Vianna-Morgante AM, Nozaki JM, Ortega CC, Coates V, Yamamura Y. Partial monosomy and partial trisomy 18 in two offspring of carrier of pericentric inversion of chromosome 18. J Med Genet 1976;13:366-70.
10 Wahrman J, Atidia J, Goitein R, et al. Pericentric inversions of chromosome 9 in two families. Cytogenetics 1972;11:132-44.

11 Betz A, Turleau C, de Grouchy J. Heterozygotie et homozygotie pour une inversion pericentrique du 3 humain. Ann Genet (Paris) 1974;17:77-80.

12 Vine DT, Yarkoni S, Cohen MM. Inversion homozygosity of chromosome no 9 in a highly inbred kindred. $\mathrm{Am} \mathrm{J}$ Hum Genet 1976;28:203-7.

13 Croquette MF, Couturier J, Dutrillaux B, et al. Presence, chez un homme sterile, de deux inversions pericentriques des chromosomes 9: inv(9) (p11q1209), inv(9) (pterq1209). Ann Genet (Paris) 1979;22:53-6.

14 Dallapiccola B, Capra L, Preto G, et al. Inversion pericentrique du 4: inv(4) (p12q35) et trisomie du bras court du 4 par aneusomie de recombinaison. Ann Genet (Paris) 1974;17:115-8.

15 Rethoré MO, Dutrillaux B, Job JC, et al. Trisomie 4p par aneusomie de recombinaison d'une inv(4) (p14q35). Ann Genet (Paris) 1974;17:109-14.

16 Soukup SW, Yarema W, Robinow M. A pericentric inversion of a chromosome 4 with a $t(4 q+10 p-)$ and a familial $t(\mathrm{DqDq})$ in a mentally retarded girl. Humangenetik $1974 ; 25$ :69-78.

17 van der Linden AGJM, Pearson PL, van de Kamp JJP. Cytological assessment of meiotic exchange in a human male with a pericentric inversion of chromosome no 4 . Cytogenet Cell Genet 1975;14:126-39.

18 Serville F, Broustet A. Pericentric inversion and partial monosomy $4 \mathrm{q}$ associated with congenital anomalies. Hum Genet 1977;39:239-42.

19 Francke U, Arias DE, Nyhan WL. Proximal 4p- deletion: phenotype differs from classical $4 \mathrm{p}$ - syndrome. $J$ Pediatr 1977;90:250-2.

20 Johnson VP, Mulder RD, Hosen R. The Wolf-Hirschhorn (4p-) syndrome. Clin Genet 1976;10:104-12.

21 Funderburk SJ, Crandall BF. Dominant piebald trait in a retarded child with a reciprocal translocation and small intercalary deletion. Am J Hum Genet 1974;26:715-22.

22 Mitchell JA, Packman S, Loughman WD, et al. Deletions of different segments of the long arm of chromosome 4 . Am J Hum Genet $1981 ; 8: 73-89$.

Requests for reprints to Dr N J Carpenter, Department of Clinical Genetics, Children's Medical Center, 5300 East Skelly Drive, Tulsa, Oklahoma 74135 , USA.

\section{The phenotype of ring chromosome 3}

SUMMARY A male child with mental retardation and poor growth was found to have a4 6,XY,r3 (p26 $\rightarrow$ q29) karyotype in $92 \%$ of his peripheral lymphocytes and $90 \%$ of his cultured fibroblasts. Comparison of this patient's dysmorphic features with previously reported cases of ring 3 or deletion $3 \mathrm{p}$ suggests a clinical syndrome derived mainly from deletion of 3 p $26 \rightarrow$ pter. The syndrome consists of mental retardation, preReceived for publication 18 March 1982. 